\begin{tabular}{|c|c|}
\hline Title & Synthesis of copper/copper oxide nanoparticles by solution plasma \\
\hline Author(s) & Saito, Genki; Hosokai, Sou; T subota, Masakatsu; A kiy ama, Tomohiro \\
\hline Citation & $\begin{array}{l}\text { Journal of A pplied Physics, } 110(2), 023302 \\
\text { https://doi.org/10.1063/1.3610496 }\end{array}$ \\
\hline Issue Date & 2011-07-15 \\
\hline Doc URL & http:/hdl.handle.net/2115/47132 \\
\hline Rights & $\begin{array}{l}\text { Copyright } 2011 \text { A merican Institute of Phy sics. This article may be downloaded for personal use only. A ny other use } \\
\text { requires prior permission of the author and the A merican Institute of Physics. The following article appeared in J. A ppl. } \\
\text { Phys. 110, } 023302 \text { (2011) and may be found at https://dx.doi.org/10.1063/1.3610496 }\end{array}$ \\
\hline Type & article \\
\hline File Information & JA P110-2_023302.pdf \\
\hline
\end{tabular}

Instructions for use 


\title{
Synthesis of copper/copper oxide nanoparticles by solution plasma
}

\author{
Genki Saito, Sou Hosokai, Masakatsu Tsubota, and Tomohiro Akiyama ${ }^{\text {a) }}$ \\ Center for Advanced Research of Energy and Materials, Hokkaido University, Sapporo 060-8628, Japan
}

(Received 15 March 2011; accepted 12 June 2011; published online 19 July 2011)

\begin{abstract}
This paper describes the synthesis of copper/copper oxide nanoparticles via a solution plasma, in which the effect of the electrolyte and electrolysis time on the morphology of the products was mainly examined. In the experiments, a copper wire as a cathode was immersed in an electrolysis solution of $\mathrm{K} \mathrm{K}_{2} \mathrm{CO}_{3}$ with the concentration from 0.001 to $0.50 \mathrm{M}$ or a citrate buffer $(\mathrm{pH}=4.8)$, and was melted by the local-concentration of current. The results demonstrated that by using the $\mathrm{K}_{2} \mathrm{CO}_{3}$ solution, we obtained $\mathrm{CuO}$ nanoflowers with many sharp nanorods, the size of which decreased with decreasing the concentration of the solution. Spherical particles of copper with/ without pores formed when the citrate buffer was used. The pores in the copper nanoparticles appeared when the applied voltage changed from $105 \mathrm{~V}$ to $130 \mathrm{~V}$, due to the dissolution of $\mathrm{Cu}_{2} \mathrm{O}$.

(C) 2011 American Institute of Physics. [doi:10.1063/1.3610496]
\end{abstract}

\section{INTRODUCTION}

Presently, nanostructured copper-based materials, including copper oxide and metallic copper, have been used in a broad range of areas. For instance, $\mathrm{CuO}$, is an important p-type transition-metal-oxide semiconductor with a narrow bandgap of $1.2 \mathrm{eV}$, and it has been widely used as a heterogeneous catalyst, gas sensor, electrode materials for lithiumiron battery, ${ }^{1,2}$ and field emission emitter. Moreover, many recent efforts have been directed toward the fabrication of nanocrystalline $\mathrm{CuO}$ to enhance its performance ${ }^{3-6}$ and develop new functions. ${ }^{7,8}$ Metallic nanoparticles of copper attract attention not only in the scientific field but also in industry because of their application in electronic devices such as printed circuit boards ${ }^{9-11}$ and multilayer ceramic capacitors. $^{12,13}$

Conventionally, copper/copper oxide nanoparticles have been produced by gas-phase and liquid-phase methods, however, both methods face great challenges. Gas-phase methods generate high-purity nanoparticles but they often require high temperatures using a chloride gases and a vacuum chamber. It is hard to disperse nanoparticles in a solvent. Conversely, liquid phase methods produce highly dispersive nanoparticles at low temperatures through the chemical reduction of the solvent; however, they require a reducing agent and long growth times for the production of nanoparticles.

In this study, we applied a solution plasma ${ }^{14-16}$ for synthesizing copper nanoparticles. The solution plasma uses a cathode of copper wire as the raw material for the nanoparticles, which is placed at the center of a beaker. The surface area of the anode is 50 times larger than the cathode. Since the IR-loss is concentrated at the cathode/solution interface, the solution near the cathode is heated to the boiling point and a gas-layer containing hydrogen gas and steam was

\footnotetext{
a) Author to whom correspondence should be addressed. Electronic mail: takiyama@eng.hokudai.ac.jp.
}

generated near the cathode. If the voltage is sufficiently high, a glow discharge with intense light emission starts in the gas-layer. It is known that the cathode can discharge at a lower cell voltage $(\sim 140 \mathrm{~V})$ than the anode. ${ }^{17,18}$ The surface of the electrode partially melts to produce nanoparticles owing to the concentration of current caused by the electrothermal instability. ${ }^{19,20}$

A solution plasma offers many advantages: (1) simple equipment, (2) no requirement of gas supply, (3) easy mass production, (4) applicability to any metals/alloys, and (5) controllable product size. According to the major databases, the production of copper/copper oxide nanoparticles via solution plasma has never been reported, in spite of its highefficacy and low-cost production. Therefore, the purpose of this paper is to study the experimental conditions that produce copper/copper oxide nanoparticles. In fact, we investigated the effect of the electrolyte solution and electrolysis time on formation of nanoparticles in a solution plasma, in which the electrolysis solution was $\mathrm{K}_{2} \mathrm{CO}_{3}$ with a concentration from 0.001 to $0.50 \mathrm{M}$ or citrate buffer $(\mathrm{pH}=4.8)$. The products obtained were characterized using field-emission electron microscopy (FE-SEM), transmission electron microscopy (TEM), X-ray diffractometry (XRD), and selected area electron diffraction (SAED) patterns. Finally, a possible mechanism for the synthesis of copper/copper oxide nanoparticles was discussed based on the results.

\section{EXPERIMENTAL METHODS}

\section{A. Experimental setup}

Figure 1 shows the experimental setup, which consists of two electrodes in a glass cell with a capacity of $300 \mathrm{ml}$. A cathode placed in the center of the glass cell was a copper wire of $1.0 \mathrm{~mm}$ in diameter and a purity of 99.9 mass\% (Nilaco, Tokyo, Japan). The upper part of the cathode electrode was shielded by a quartz-glass tube to obtain an exposed length of $10 \mathrm{~mm}$; the exposed part functioned as the actual electrode. The anode was a platinum wire, which was 


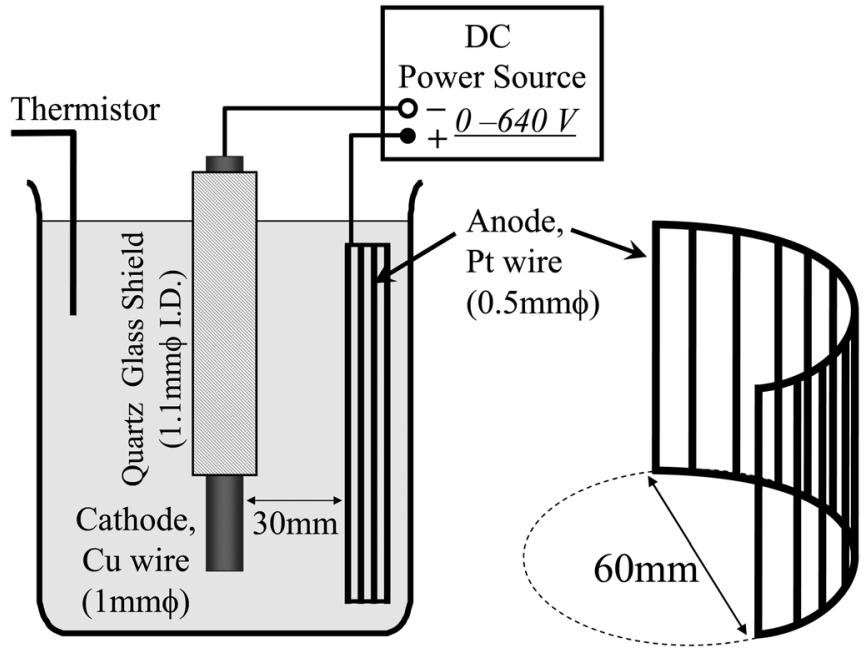

FIG. 1. Schematic diagram of the experimental apparatus of plasma electrolysis for the synthesis of $\mathrm{Cu}$ nanoparticles. The only exposed part with length of $20 \mathrm{~mm}$ worked as an electrode. Anode of a platinum wire, which was bent into a half-round mesh with a length of $1000 \mathrm{~mm}$, a diameter of 0.5 $\mathrm{mm}$ and the distance between both electrodes was kept to be $30 \mathrm{~mm}$, as shown in the corresponding cubic diagram.

bent into a half-round mesh with a length of $1000 \mathrm{~mm}$, a diameter of $0.5 \mathrm{~mm}$, and a purity of 99.98 mass\% (Nilaco, Tokyo, Japan). The cubic diagram in the right side of Fig. 1 shows the shape of the anode electrode. The surface area of the anode was 50 times larger than the cathode. The distance between the electrodes was kept at $30 \mathrm{~mm}$. The glow discharge plasma was generated around the cathode and was maintained by applying a voltage from a direct-current power supply (ZX800 H, Takasago, Tokyo, Japan).

\section{B. Nanoparticles synthesis and characterization}

We used $\mathrm{K}_{2} \mathrm{CO}_{3}$ solutions as electrolytes with concentrations of 0.5 to $0.001 \mathrm{M}$ or citrate buffer $(\mathrm{pH}=4.8)$. When the electrolyte was citrate buffer, the effects of the electrolysis time and applied voltage on the product morphology were investigated; the electrolysis times were 60 and $5 \mathrm{~min}$,

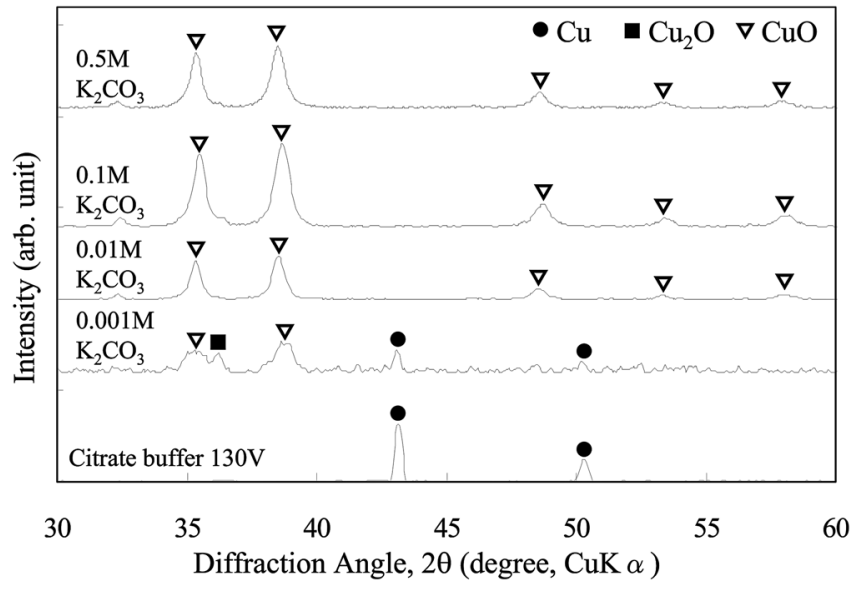

FIG. 2. XRD patterns of the products, which were collected by centrifugation, washed with de-ionized water, and dried. When a citrate buffer solution was used as an electrolyte with a $\mathrm{pH}$ of 4.8 , only metallic copper formed.

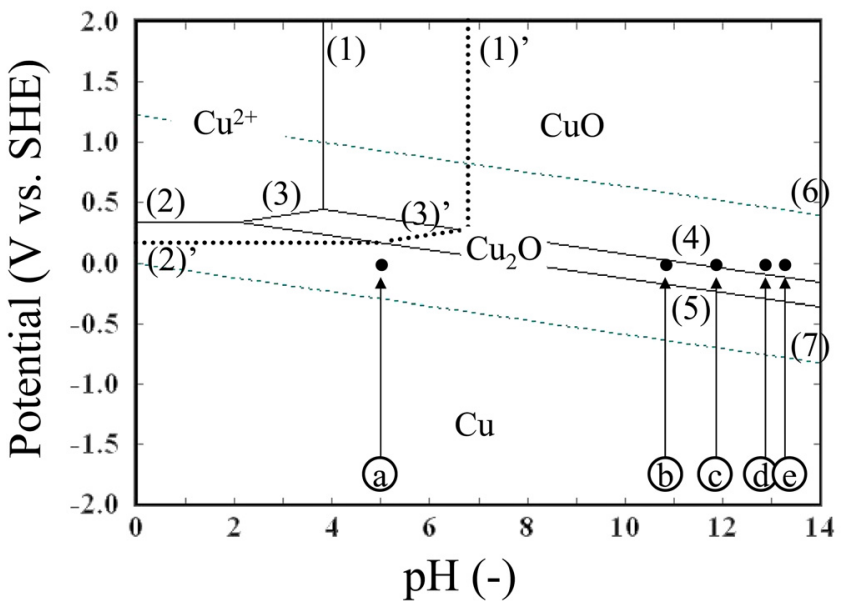

FIG. 3. (Color online) $\mathrm{Cu} \mathrm{E}-\mathrm{pH}$ diagram under the assumption of $\left[\mathrm{Cu}^{2+}\right]=1.0 \mathrm{~mol} / \mathrm{kg}$ (solid line) and $\left[\mathrm{Cu}^{2+}\right]=1.0 \times 10^{-6} \mathrm{~mol} / \mathrm{kg}$ (dotted line); (1) $\mathrm{CuO}+2 \mathrm{H}^{+}=\mathrm{Cu}^{2+}+\mathrm{H}_{2} \mathrm{O}$; (2) $\mathrm{Cu}^{2+}+2 \mathrm{e}^{-}=\mathrm{Cu}$; (3) $\mathrm{Cu}_{2} \mathrm{O}+2$ $\mathrm{H}^{+}=2 \mathrm{e}^{-}+2 \mathrm{Cu}^{2+}+\mathrm{H}_{2} \mathrm{O} ;$ (4) $2 \mathrm{CuO}+2 \quad \mathrm{H}^{+}+2 \mathrm{e}^{-}=\mathrm{Cu}_{2} \mathrm{O}+\mathrm{H}_{2} \mathrm{O}$; (5) $\mathrm{Cu}_{2} \mathrm{O}+2 \mathrm{H}^{+}+2 \mathrm{e}^{-}=2 \mathrm{Cu}+\mathrm{H}_{2} \mathrm{O}$; (6) $2 \mathrm{H}_{2} \mathrm{O}=\mathrm{O}_{2}+4 \mathrm{H}^{+}+4 \mathrm{e}^{-}$; and (7) 2 $\mathrm{H}^{+}+2 \mathrm{e}^{-}=\mathrm{H}_{2}$. The plots show the $\mathrm{pH}$ of solutions which were used in the experiments; (a) citrate buffer $(\mathrm{pH}=4.8)$, (b) $0.001 \mathrm{M} \mathrm{K}_{2} \mathrm{CO}_{3}$; (c) $0.01 \mathrm{M}$ $\mathrm{K}_{2} \mathrm{CO}_{3}$; (d) $0.01 \mathrm{M} \mathrm{K}_{2} \mathrm{CO}_{3}$; and (e) $0.5 \mathrm{M} \mathrm{K}_{2} \mathrm{CO}_{3}$. SHE means standard hydrogen electrode.

and the applied voltages were 105 and $130 \mathrm{~V}$. After the experiments, the products were collected by the centrifugation. The collected particles were washed with a de-ionized water to remove solidified salts. After drying, the particles were characterized by XRD using a Miniflex II (Rigaku, Tokyo, Japan) diffractometer. The surface of the cathode after the experiments and the products were observed by FESEM using a JSM-7001 F (JEOL, Tokyo, Japan) microscope, transmission electron microscopy (TEM) using a H-700 (Hitachi High-Technologies, Japan) microscope, Highresolution TEM (HR-TEM), and selected area electron diffraction (SAED) patterns using a JEM-2010 F (JEOL, Tokyo, Japan) microscope.

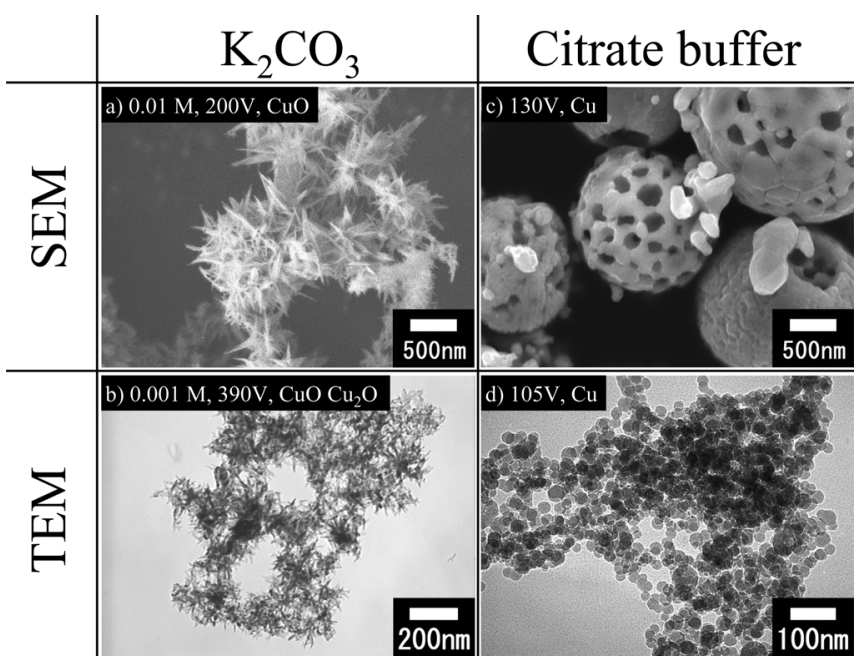

FIG. 4. SEM and TEM images of the products. The upper captions show the concentration of the electrolyte, the applied voltage, and phase. The phase of the product was identified by X-ray and electron diffraction. 

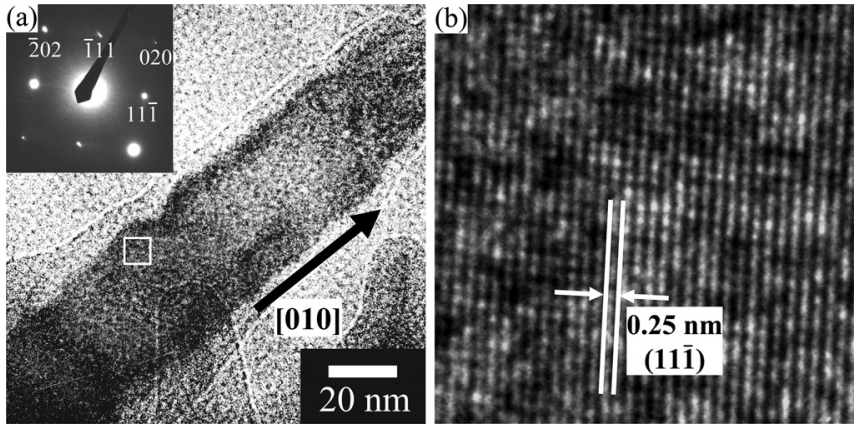

FIG. 5. (a) TEM image of a $\mathrm{CuO}$ nanorod peeled from the $\mathrm{CuO}$ nanoflower $\left(0.01-\mathrm{M} \mathrm{K}_{2} \mathrm{CO}_{3}\right)$ and its corresponding SAED pattern. (b) High-resolution TEM image.

\section{RESULTS AND DISCUSSION}

\section{A. Influence of electrolyte}

Electrolytes of 0.5 to $0.001 \mathrm{M} \mathrm{K}_{2} \mathrm{CO}_{3}$ solution and citrate buffer $(\mathrm{pH}=4.8)$ were used to investigate the influence of the electrolyte. According to the XRD patterns of the products (Fig. 2), metallic copper formed when using the citrate buffer solution. When a $\mathrm{K}_{2} \mathrm{CO}_{3}$ solution was used, copper oxide formed in all concentrations of the electrolyte. Figure 3 shows the copper E-pH diagram and explains which phase is electrochemically stable. Before the electrodes were connected to the power supply, the potential was zero. The copper cathode was charged negatively during the electrolysis, which stabilized metallic copper. When the cathode surface was melted to generate nanoparticles, the particles peeled from the surface had zero potential. Plots show the $\mathrm{pH}$ of solutions used in the experiments: (a) citrate buffer $(\mathrm{pH}=4.8)$; (b) $0.001 \mathrm{M} \mathrm{K}_{2} \mathrm{CO}_{3}$; (c) $0.01 \mathrm{M} \mathrm{K}_{2} \mathrm{CO}_{3}$; (d) $0.01 \mathrm{M} \mathrm{K}_{2} \mathrm{CO}_{3}$; and (e) $0.5 \mathrm{M} \mathrm{K}_{2} \mathrm{CO}_{3}$. According to this diagram, copper is easily forms $\mathrm{CuO}$ in the case of (c), (d), and (e). In addition, $\mathrm{Cu}_{2} \mathrm{O}$ becomes stable in (b). In case of (a), the citrate buffer solution $(\mathrm{pH}=4.8)$, metallic copper is generated. The theoretical results agree well with the XRD patterns (Fig. 2). These results revealed that the phase of the product is controlled by the solution $\mathrm{pH}$.

\section{B. Formation mechanism of the products}

Figure 4 shows the SEM and TEM images of the products, in which the use of $\mathrm{K}_{2} \mathrm{CO}_{3}$ solution yielded flower-like products including many nanorods [Figs. 5(a) and 5(b)].
Interestingly, the product size decreased with the decrease in the electrolyte concentration because of the high applied voltage. ${ }^{16}$ Figure 5 (a) shows a typical TEM image of the nanorod peeled from the $\mathrm{CuO}$ nanoflowers (0.01-M K2CO3, $200 \mathrm{~V}$ ), the inset of which is an SAED pattern taken from one of the nanorods. This confirmed the single crystal of the $\mathrm{CuO}$ grown along the [010] direction. Further, an HR-TEM image, shown in Fig. 5(b), revealed a lattice fringe of approximately $0.25 \mathrm{~nm}$, which corresponded to the (11[mac]1) plane of the CuO. Previously, the solution plasma had produced spherical nanoparticles as following steps; first, the surface of the cathode melted. Secondary, the molten metal formed sphere due to the surface tension in the solution, and then was solidified to form spherical nanoparticles. ${ }^{14-16}$ However, the flower-like products formed due to another mechanism, which was not solidification after melting but nucleation and crystal growth. The flower-like $\mathrm{CuO}$ have been produced through a hydrothermal synthesis, ${ }^{2,21-24}$ solution routes ${ }^{4,8,25-30}$ and microwave irradiation. ${ }^{31}$ The growth unit of $\mathrm{CuO}$ nanoflowers in these methods is a $\left[\mathrm{Cu}(\mathrm{OH})_{4}\right]^{2-}$ ions. Here, we consider the formation mechanism of the flower-like $\mathrm{CuO}$ in the following three steps. First, the surface of the $\mathrm{Cu}$ electrode forms $\mathrm{Cu}(\mathrm{OH})_{2}$ by steam corrosion at a high temperature, as shown in Eq. (1). The reaction proceeds at over $260^{\circ} \mathrm{C}$ because the temperature of the solution surrounding the cathode is high enough to melt copper. Second, the product $\mathrm{Cu}(\mathrm{OH})_{2}$ reacts with the hydroxide ion to produce so-called "tetrahydroxocuprate (II) anions", $\left[\mathrm{Cu}(\mathrm{OH})_{4}\right]^{2-},{ }^{23,27}[$ Eq. (2)]. Then, solid $\mathrm{CuO}$ precipitates with a decrease in temperature via reaction (3). The growth rates of $\mathrm{CuO}$ are different for each crystal plane as reported by Yang et al. ${ }^{27}$; growth rates is $[010]>[100]>$ [001] Because of the high growth rate along the [010] direction, $\mathrm{CuO}$ crystals grew preferentially along the [010] direction to form flower-like particle.

$$
\begin{gathered}
2 \mathrm{H}_{2} \mathrm{O}+\mathrm{Cu}_{(\mathrm{s})} \rightarrow \mathrm{Cu}(\mathrm{OH})_{2(\mathrm{~s})}+\mathrm{H}_{2(\mathrm{~g})}, \\
\mathrm{Cu}(\mathrm{OH})_{2(\mathrm{~s})}+2 \mathrm{OH}_{(\mathrm{aq})}^{-} \rightarrow\left[\mathrm{Cu}(\mathrm{OH})_{4}\right]_{(\text {aq })}^{2-}, \\
{\left[\mathrm{Cu}(\mathrm{OH})_{4}\right]_{(\mathrm{aq})}^{2-} \rightarrow \mathrm{CuO}_{(\mathrm{s})}+\mathrm{H}_{2} \mathrm{O}+2 \mathrm{OH}_{(\mathrm{aq})}^{-} .}
\end{gathered}
$$

Spherical particles of copper were also produced when using citrate buffer as the electrolyte [see Figs. 5(c) 5(d)]. In addition, the particles synthesized by applying a voltage of $130 \mathrm{~V}$ had

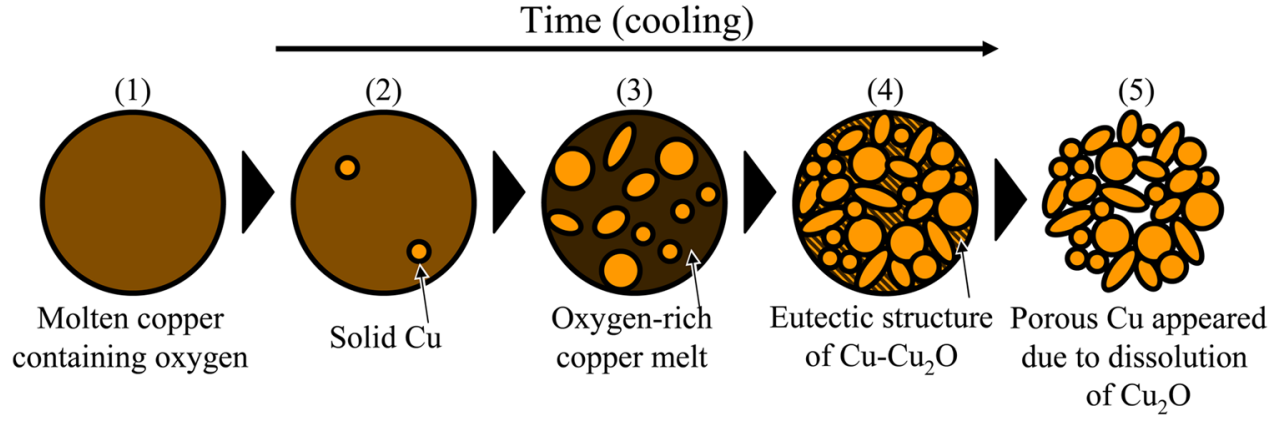

FIG. 6. (Color online) Formation mechanism of porous copper particles. The liquid solidifies to form crystals of pure Copper (2). As the temperature decreases, the liquid becomes richer in oxygen (3). When solidification is complete, the eutectic microstructure of $\mathrm{Cu}$ $\mathrm{Cu}_{2} \mathrm{O}$ appears as shown in (4). The phase of $\mathrm{Cu}_{2} \mathrm{O}$ dissolved to produce porous particle. 


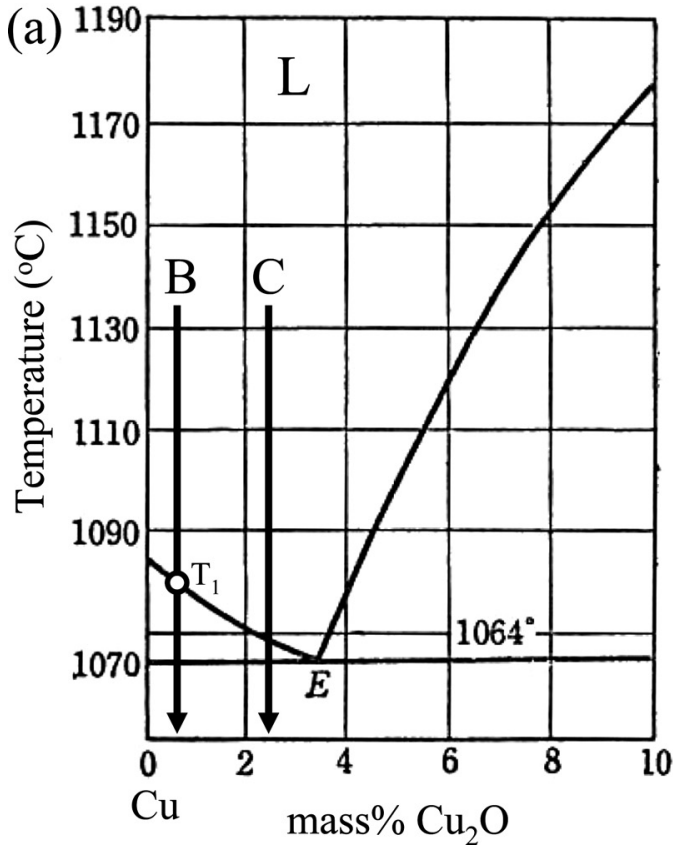

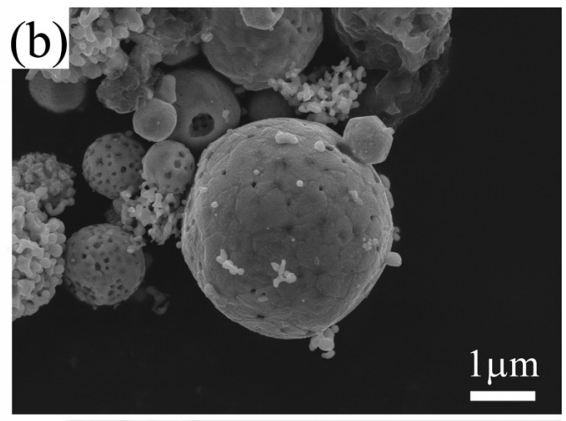

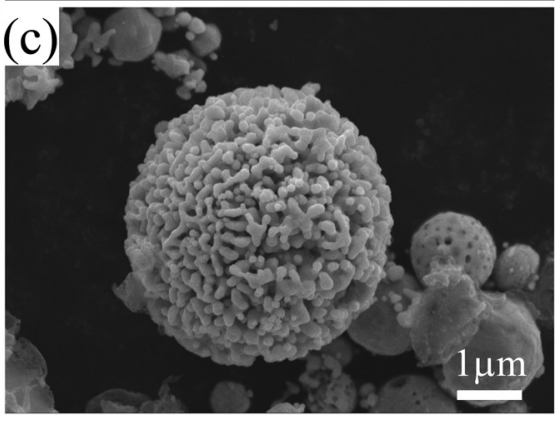

FIG. 7. (a) $\mathrm{Cu}-\mathrm{Cu}_{2} \mathrm{O}$ phase diagram (see Ref. 19). The difference in the product morphology is explained by the oxygen concentration. When a molten copper slightly oxidizes as shown with arrow $\mathrm{B}$, the ratio of $\mathrm{Cu}_{2} \mathrm{O}$ decreases to form spherical particles with a few pores. Conversely, with a high concentration of oxygen shown with arrow $\mathrm{C}$, the particles with many pores form. (b) and (c) Corresponding SEM images. many pores with a particle diameter of less than $100 \mathrm{~nm}$. The partially melt of the electrode led to the formation of spheres. A higher voltage increased the temperature of the electrode surface, and thereby the electrode oxidized. The oxidized electrode melted to produce copper melt containing oxygen (Fig. 6). Molten copper containing oxygen remains liquid until the temperature reaches the liquidus line, as shown in the phase diagram ${ }^{32}$ [see Fig. 7(a) ${ }^{33}$ ]. At the liquidus [see $\mathrm{T}_{1}$ in Fig. 7(a)], the liquid solidifies to form crystals of pure copper [Fig. 6(2)]. As the temperature decreases, the liquid becomes richer in oxygen [Fig. 6(3)]. When it reaches the eutectic temperature E, there are two phases, solid copper and molten copper containing $\mathrm{Cu}_{2} \mathrm{O}$ with a concentration of 3.4 mass $\%$. When the solidification is complete, the eutectic microstructure of $\mathrm{Cu}-\mathrm{Cu}_{2} \mathrm{O}$ appears [Fig. 6(4)]. Solid $\mathrm{Cu}_{2} \mathrm{O}$ is dissolved as shown in follow- ing Eq. (4), which reaction proceeds at under $290^{\circ} \mathrm{C}$, and a $\mathrm{pH}$ of 4.8 to produce porous particles.

$$
\mathrm{CuO}(\mathrm{s})+2 \mathrm{H}_{(\mathrm{aq})}^{+} \rightarrow \mathrm{Cu}_{(\mathrm{aq})}^{2+} \mathrm{Cu}_{(\mathrm{s})}+\mathrm{H}_{2} \mathrm{O}
$$

Moreover, the proportion of pores in the particles varies. This difference in product morphology is explained by the oxygen concentration. When molten copper slightly oxidizes, as shown by the $\mathrm{B}$ arrow in Fig. 7(a), the ratio of $\mathrm{Cu}_{2} \mathrm{O}$ decreases to form spherical particles having few pores. Conversely, with a high concentration of oxygen, as shown with the $\mathrm{C}$ arrow, particles with many pores form. Figure 7(b) and 7(c) show the SEM images of the porous $\mathrm{Cu}$ product obtained at different concentrations of oxygen, as shown in arrows B and C in Fig. 7(a). (a)
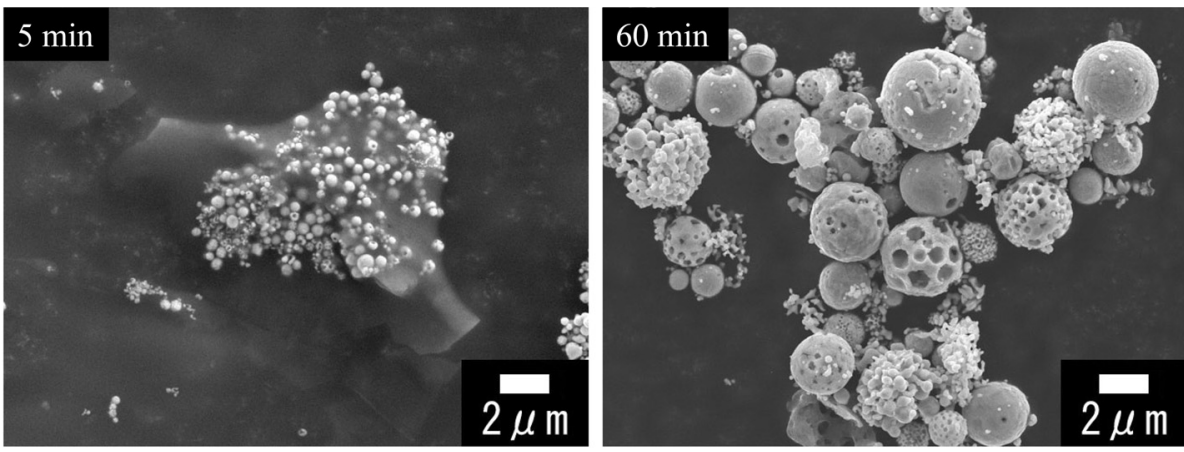

(b)

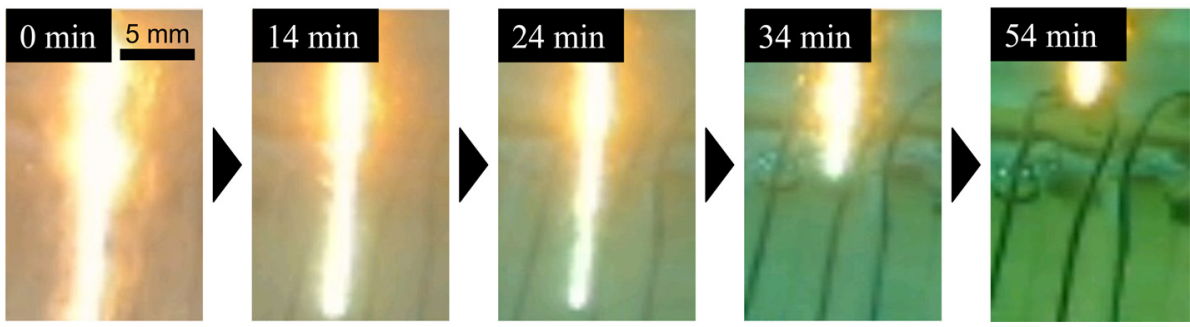

FIG. 8. (Color online) (a) SEM images of the product at different periods during electrolysis: $5 \mathrm{~min}$ and $60 \mathrm{~min}$. The product became larger in size. (b) Histories of cathode electrodes during electrolysis. The edge of the cathode was gradually consumed. 


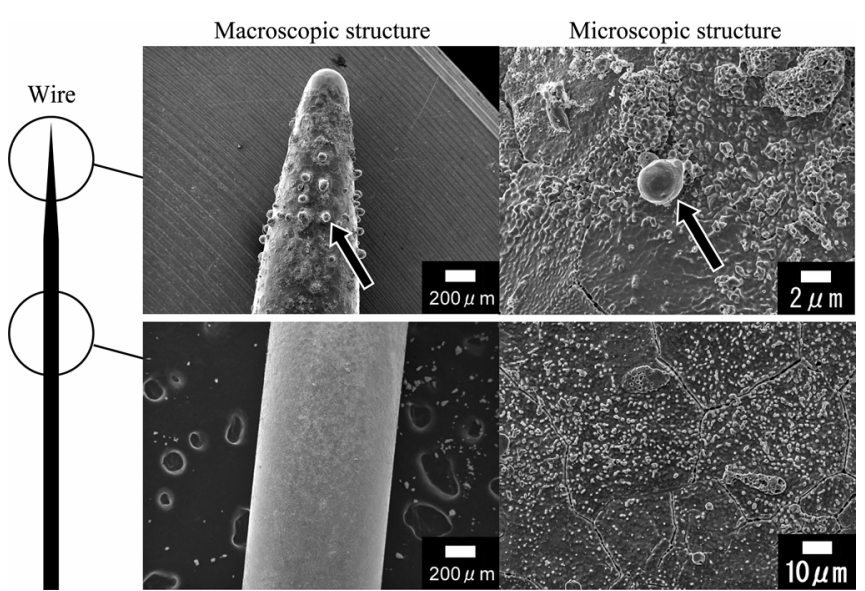

FIG. 9. SEM images of the cathode surface, which were observed after the experiments. Coarse particles with a diameter over $1 \mathrm{~mm}$ attached to the edge of the electrode (see arrows).

\section{Influence of electrolysis time}

We also controlled the time of plasma electrolysis at 60 min and 5 min under the condition of citrate buffer solutions as the electrolyte. According to the SEM images of the products produced at the different times of electrolysis [Fig. $8(a)$ ], it was found that the particle size became larger with time; the product size reached $500 \mathrm{~nm}$ after $5 \mathrm{~min}$ and $2 \mu \mathrm{m}$ after $60 \mathrm{~min}$. Figure 8(b) shows the histories of the cathode electrodes during electrolysis, in which the edge of the cathode was gradually consumed with time. The results indicated that products were mainly generated at the tip of the electrode. To understand why particles became larger with time, we observed the electrode surface after the experiments using FE-SEM. Figure 9 shows the SEM images of the cathode surface which were observed after experiments. The SEM images revealed that the wire tip became thinner, and the larger particles with a diameter of over $1 \mu \mathrm{m}$ were attached to the edge of the electrode (see arrows). The current was concentrated on the tip due to the highly inhomogeneous electric field, and then, the tip of the electrode was heated up to form the coarse particles. The experimental conditions for the preparation of $\mathrm{Cu}$ and $\mathrm{CuO}$ nanostructures are summarized in Table I.

TABLE I. Summary of experimental conditions and products morphologies.

\begin{tabular}{lccc}
\hline \hline Electrolyte & $\begin{array}{c}\text { Electrolysis } \\
\text { Time (min) }\end{array}$ & $\begin{array}{c}\text { Applied } \\
\text { Voltage (V) }\end{array}$ & Morphology \\
\hline $0.5 \mathrm{M} \mathrm{K}_{2} \mathrm{CO}_{3}$ & 60 & 80 & Flower-like CuO \\
$0.1 \mathrm{M} \mathrm{K}_{2} \mathrm{CO}_{3}$ & 60 & 130 & Flower-like CuO \\
$0.01 \mathrm{M} \mathrm{K}_{2} \mathrm{CO}_{3}$ & 60 & 200 & Flower-like CuO \\
$0.001 \mathrm{M} \mathrm{K}_{2} \mathrm{CO}_{3}$ & 60 & 390 & Flower-like CuO \\
$\begin{array}{l}\text { Citrate buffer } \\
(\mathrm{pH}=4.8)\end{array}$ & 60 & 105 & Cu Sphere \\
$\begin{array}{l}\text { Citrate buffer } \\
(\mathrm{pH}=4.8)\end{array}$ & 60 & 130 & Cu Porous sphere \\
Citrate buffer & 5 & 130 & Cu Porous sphere \\
$(\mathrm{pH}=4.8)$ & & & \\
\hline \hline
\end{tabular}

\section{CONCLUSIONS}

In this paper, we studied the relationship between the experimental conditions and the formation of copper/copper oxide nanoparticles via a solution plasma, and concluded the following:

(1) Flower-like $\mathrm{CuO}$ with many nanorods under $100 \mathrm{~nm}$ in diameter and a [010] orientation in the growth direction were synthesized because of the formation of $\left[\mathrm{Cu}(\mathrm{OH})_{4}\right]^{2-}$ ions and oriented crystal growth. In addition, the particle size of $\mathrm{CuO}$ decreased with decreasing concentration of the $\mathrm{K}_{2} \mathrm{CO}_{3}$ electrolyte.

(2) The application of the citrate buffer solution yielded metallic copper nanoparticles, whose shape changed according to the applied voltage: spherical particles at an applied voltage of $105 \mathrm{~V}$ and porous spherical nanoparticles at $130 \mathrm{~V}$.

(3) The size of the porous copper nanoparticles increased with electrolysis time due to the thinning of the electrode tip with time.

(4) The porous copper nanoparticles appeared due to the dissolution of $\mathrm{Cu}_{2} \mathrm{O}$.

The results will also offer many benefits for production of copper/copper oxide nanoparticles in easily and quickly. The prepared $\mathrm{CuO}$ nanoflowers can be used to construct the electrode of lithium ion battery, and $\mathrm{Cu}$ nanoparticles is an attractive material for conductive paste.

\section{ACKNOWLEDGMENTS}

The authors would like to thank Seiichi Watanabe, Shigeo Yatsu and Souki Yoshida for many helpful discussions. The authors also thank Kenji Ohkubo for taking the electron micrographs.

${ }^{1}$ S.-F. Zheng, J.-S. Hu, L.-S. Zhong, W.-G. Song, L.-J. Wan, and Y.-G. Guo, Chem. Mater. 20, 3617 (2008).

${ }^{2}$ G. Zou, H. Li, D. Zhang, K. Xiong, C. Dong, and Y. Qian, J. Phys. Chem. B 110, 1632 (2006).

${ }^{3}$ X. Wang, C. Hu, H. Liu, G. Du, X. He, and Y. Xi, Sens. Actuators B 144, 220 (2010).

${ }^{4}$ J.-Y. Li, S. Xiong, B. Xi, X.-G. Li, and Y.-T. Qian, Cryst. Growth Des. 9, 4108 (2009).

${ }^{5}$ S. Sahoo, S. Husale, B. Colwill, T.-M. Lu, S. Nayak, and P. M. Ajayan, ACS Nano 3, 3935 (2009).

${ }^{6}$ H. Wu, D. Lin, and W. Pan, Appl. Phys. Lett. 89, 133125 (2006).

${ }^{7}$ X. Zheng, H. Kubozono, H. Yamada, K. Kato, Y. Ishiwata, and C. Xu, Nat. Nanotechnol. 3, 724 (2008).

${ }^{8}$ P. Gao, Y. Chen, H. Lv, X. Li, Y. Wang, and Q. Zhang, Int. J. Hydrogen Energy 34, 3065 (2009).

${ }^{9}$ M. Nakamoto, IEIC Technical Report 106, 37 (2007).

${ }^{10}$ B. K. Park, S. Jeong, D. Kim, J. Moon, S. Lim, and J. S. Kim, J. Colloid Interface Sci. 311, 417 (2007).

${ }^{11}$ X.-F. Tang, Z.-G. Yang, and W.-J. Wang, Colloids Surf A 360, 99 (2010).

${ }^{12}$ T. Yonezawa, J. Surf. Finishing Soc. Jpn. 59, 712 (2008).

${ }^{13}$ T. Yonezawa, S. Takeoka, H. Kishi, K. Ida, and M. Tomonari, Nanotechnology 19, 145706 (2008).

${ }^{14}$ K. Azumi, A. Kanada, M. Kawaguchi, and M. Seo, Hyomen Gijutsu 56, 938 (2005).

${ }^{15}$ Y. Toriyabe, S. Watanabe, S. Yatsu, T. Shibayama, and T. Mizuno, Appl. Phys. Lett. 91, 041501 (2007).

${ }^{16}$ G. Saito, S. Hosokai, T. Akiyama, S. Yoshida, S. Yatsu, and S. Watanabe, J. Phys. Soc. Jpn. 79, 083501 (2010).

${ }^{17}$ S. K. Sengupta, R. Singh, and A. K. Srivastava, J. Electrochem. Soc. 145, 2209 (1998). 
${ }^{18}$ A. L. Yerokhin, X. Nie, A. Leyland, A. Matthews, and S. J. Dowey, Surf. Coatings Technol. 122, 73 (1999).

${ }^{19}$ K. Okazaki, Y. Mori, K. Hijikata, and K. Ohtake, AIAA J. 16, 334 (1978).

${ }^{20}$ R. Uncles and A. Nelson, Plasma Phys. 12, 917 (1970).

${ }^{21}$ Q. Liu, H. Liu, Y. Liang, Z. Xu, and G. Yin, Mater. Res. Bull. 41, 697 (2006).

${ }^{22}$ Y. Liu, Y. Chu, Y. Zhuo, M. Li, L. Li, and L. Dong, Cryst. Growth Des. 7 , 467 (2007).

${ }^{23}$ Y. Cudennec and A. Lecerf, Solid State Sci. 5, 1471.

${ }^{24}$ H. Zhang, S. Li, X. Ma, and D. Yang, Mater. Res. Bull. 43, 1291 (2008).

${ }^{25}$ M. Vaseem, A. Umar, S. H. Kim, and Y.-B. Hahn, J. Phys. Chem. C 112, 5729 (2008).
${ }^{26}$ X. Wang, G. Xi, S. Xiong, Y. Liu, B. Xi, W. Yu, and Y. Qian, Cryst. Growth Des. 7, 930 (2007).

${ }^{27}$ L.-X. Yang, Y.-J. Zhu, H. Tong, L. Li, and L. Zhang, Mater. Chem. Phys. 112, 442 (2008).

${ }^{28}$ Y. Li, X.-Y. Yang, J. Rooke, G. V. Tendeloo, and B.-L. Su, J. Colloid Interface Sci. 348, 303 (2010).

${ }^{29}$ Y. Zhao, J. Zhao, Y. Li, D. Ma, S. Hou, L. Li, X. Hao, and Z. Wang, Nanotechnology 22, 115604 (2011).

${ }^{30}$ Y. Chang and H. C. Zeng, Cryst. Growth Des. 4, 397 (2003).

${ }^{31}$ X. Xu, M. Zhang, J. Feng, and M. Zhang, Mater. Lett. 62, 2787 (2008).

${ }^{32}$ S. H. Avner, Introduction to Physical Metallurgy, 2nd ed. (McGraw-Hill, New York, 1974).

${ }^{33}$ M. Sugiyama, Non-Ferrous Materials (Corona Publishing, Tokyo, Japan, 1963). 